\title{
35 \\ ON THE NEED TO TRANSFORM GOVERNANCE TO REGULATE CORPORATIONS FOR THE SURVIVAL OF HOMO SAPIENS
}

PETER TAIT

\section{Abstract}

Widespread concerns about the state of health in the modern world, and in parallel about the increasingly damaged state of the environment, lead many to conclude that humanity's future is bleak. Many piecemeal solutions are attempted. However, using a primary health-care lens and looking for common causes that permit strategic action for finding solutions. I argue that the ultimate cause of our concerns is poorly regulated corporate behaviour within a capitalist, market-oriented politico-economic system. To rectify this governance failure, we need to reassert democratic control over governments. A programme is required to reform government and transform societal and corporate governance to make them democratically responsive to the needs of society and the environment.

\section{Focusing on Social Determinants of Health}

Dire warnings of the deleterious human effects on ecosystems and their consequences have been made for decades (McMichael, 1993; Rockström et al., 2009; McMichael and Butler, 2011). The primary health-care approach and social determinants of health theory show that health is promoted, or not, by how we arrange society (World Health Organization, 1986; Marmot and Wilkinson, 2006; Commission on Social Determinants of Health, 2008). 
Extending this approach to seek common origins of and linkages between humanity's health, social and environmental problems permits a strategic approach to address the causes of the causes. Indeed, humanity's ability to survive requires working this far upstream.

\section{The Need for Regulated Markets and Limiting Corporate Influence}

Our current social arrangements have arisen from the co-evolution of several intersecting political, economic and technological strands (Fotopoulos, 1997; Christian, 2004; Attali, 2009). The present capitalist, liberal democratic socio-economic system focuses on increasing material prosperity through growing production and consumption. Economic and social relationships are transacted within an unregulated market. Profit for shareholders trumps all other considerations, including consumer and environmental well-being (Hastings, 2012).

Large corporations have become the dominant players in the current economic and political system. Corporations use their wealth and power to influence governments to maintain the economic system that furthers their interests (Denniss and Richardson, 2013). Meaningful citizen involvement in governance is undermined (Korten, 1996). The outputs of this system are increasing wealth disparity, unhealthy people, an exploding human population and environmental and ecological destruction. By overloading the natural world on which society relies, corporations are facilitating catastrophic declines in all that sustains life (McMichael, 1993; Commission on Social Determinants of Health, 2008; Harvey, 2011).

\section{Corporations versus Democratic Processes}

The determining cause of the current social and environmental situation is poorly regulated corporate behaviour. Corporate influence undermines government capacity to do this effectively (Korten, 1996). Denniss and Richardson (2013) provide examples of how, in recent Australian history, actions by banking, mining and gambling corporations have undermined government ability to rule in the interests of the whole of society. They note 'Big business exerts influence through campaign contributions, influence over university funding, sponsorship of think tanks and in other ways that create an agenda for low tax 
for the rich, low entitlements for the poor and poor services for the middle class. In articulating why he wrote his book, Sachs (2011) argued that democracy itself was being threatened by the power and corruption of big business' (p. 2).

Denniss and Richardson (2013, p. 6) concluded: 'Reforms such as the mining tax, the carbon tax and gambling reform ... have been vetoed by the affected industries and, with such a veto in place, the government has found it virtually impossible to implement their reforms in their original guise'.

The societal influence of corporations happens at a more insidious level. Corporate ideology has colonised global society, not as geographical annexation of land and resources, but by retelling the narrative of Western society, redefining democracy, societal relations between people, between society and the environment, the nature of business, the economy and the role of government (Deetz, 1992). This narrative serves corporate ends for growth and concentrating wealth, and it warps the narrative necessary for a healthy, biosensitive (Boyden, 2010) society.

Government's role is to regulate society and corporations, via effective legislation and enforcement mechanisms and by influencing social norms. Consequently, I argue that a primary focus on corporate behaviour and regulating that behaviour will permit a biosensitive society to emerge.

The mechanism to change how governments act to reduce the power of the corporate sector is to increase the power of the citizen. This will require a democratising transformation of governance. In order to transform democracy, we need to explore what it is. Current liberal democracy lacks meaningful citizen involvement. It is electoral oligarchy (Burnheim, 1985). Elections are open to manipulation by vested interests. The only 'actual operating democracy' that we have record of is classical Athens, which provides a template on which to model a reformed democracy (Burnheim, 1985; Fishkin, 1991; Fotopoulos, 1997).

A set of common elements and principles pertain to 'real' democracy. The key is a method for making decisions by those who have to live with the consequences of those decisions. This is also a core primary health-care principle. A second set of elements recognises that decisions need to be made deliberatively, that is as an informed group considering its 'enlightened self-interest'.

The most vexatious issue in societies with large populations is that decision making requires some form of representation. As noted, representation by election is harmful. The cleanest method for representation is by statistical sampling from among those eligible. Elections are replaced by a lottery. Eligibility for standing requires criteria, which can be provided by a methodology such 
as Ulrichian boundary critique (Ulrich, 2005). Representation must embody the principle of 'every vote has the same value'. It must avoid vested interests gaining influence over decisions.

Finally, democratic institutional frameworks should be arranged to distribute political, economic and social power equally, and to constrain human ability to damage the natural world (Fotopoulos, 1997). The programme for rejuvenating democracy will require simultaneous reform of government and transformation of governance at the community level. Meadow's model for systemic change gives us a way for prioritising where we might apply levers for change (Meadows, 1999). Additionally, this model lends support to the view that a focus on governance reform is important.

\section{Processes of Change}

Societal change only occurs in response to action by, to paraphrase Margaret Mead, small numbers of concerned citizens. Citizens act through non-governmental organisations (NGOs), and together these make up civil society. Coalitions of NGOs create the social movements necessary to pressure government and the corporate sector to reform.

Changing the dominant paradigm has the highest-level impact. However, we know that changing attitudes and beliefs is the most difficult. Instead, changing people's behaviour leads to changes in beliefs as they seek to rationalise new behaviour (Nisbett and Wilson, 1977). So, a focus on changing government and institutional system-level behaviour is likely to be more effective in the short term. Governance and institutional reform will be synergistic.

Simultaneously, at the community level, a transformative process to strengthen democracy within communities, workplaces, municipalities and grassroots organisations, and to build momentum for more widespread societal transformation, is required. The Transition Towns movement is an example of this in practice (Hopkins, 2009). Corporations themselves require transformation internally to democratise their governance and operations.

It is beyond the scope of this essay to discuss the spatial, geographic and temporal scales of transformation. Suffice it to say that modern democracy will have to accommodate the globalisation of our society and our economy, as well as recognise the standing of other species, the ecosystem and future generations. 


\section{Democratic Society, Better Health}

Demonstrating empirically how a more democratic society regulating corporate behaviour achieves improved environmental, public and individual health is difficult. Three lines of evidence exist. First, the primary health-care model holds individual and community empowerment central to achieving better health (World Health Organization, 1986a). Democratic governance is the method for that empowerment to emerge. Second is evidence for the reverse occurring, as decreasing democracy and increasing inequality in the current socio-economic system drives societal unrest, poor health and environment damage (Commission on Social Determinants of Health, 2008; Rockström et al., 2009; Wilkinson and Pickett, 2009; McMichael and Butler, 2011). Third, the principles underlying diverse polycentric institutions that produce more effective natural resource management (Ostrom, 2009) approximate those of democracy outlined above, supporting the notion that more democratic institutions can produce better outcomes.

\section{Conclusion}

Framing the current human health situation on the one hand and the environmental/ecological situation on the other as consequent to poorly regulated corporate behaviour, and thus as a governance problem, provides a systemic, strategic focus for solutions. Citizens, NGOs and all aspects of civil society can become active in movements to transform government democratically. Individually, we need to continue to strongly promote democratic governance arrangements into the processes of our social, work and home lives. Focusing thus takes the foundational work of Tony McMichael, alerting us to the consequences of rampant corporations, forward towards action for healthier and ecologically sustainable human societies and a healthier, humanity-sustaining environment.

\section{References}

Attali, J. 2009. A Brief History of the Future. Allen \& Unwin, Crows Nest, NSW, Australia.

Boyden, S. 2010. Our Place in Nature: Past Present and Future. Nature and Society Forum Inc, Canberra, ACT, Australia.

Burnheim, J. 1985. Is Democracy Possible?: The Alternative to Electoral Politics. University of California Press, Oakland, California, USA. 
Christian, D. 2004. Maps of Time: An Introduction to Big History. University of California Press, Berkeley, California, USA, Los Angeles, California, USA, and London, UK.

Commission on Social Determinants of Health 2008. Closing the Gap in a Generation: Health Equity Through Action on the Social Determinants of Health: Final Report of the Commission on Social Determinants of Health. World Health Organization, Geneva, Switzerland.

Deetz, S.A. 1992. Democracy in Age Corp Co: Developments in Communication and the Politics of Everyday Life. SUNY Press, Albany, New York, USA.

Denniss, R. \& Richardson, D. 2013. Corporate power in Australia, Policy Brief No. 45. The Australia Institute, Canberra, ACT, Australia.

Fishkin, J.S. 1991. Democracy and Deliberation: New Directions for Democratic Reform. Yale University Press, New Haven, Connecticut, USA, and London, UK.

Fotopoulos, T. 1997. Towards an Inclusive Democracy: The Crisis of the Growth Economy and the Need for a New Liberatory Project. Cassell, London and New York, USA.

Harvey, D. 2011. The Enigma of Capitalism and the Crises of Capitalism. Oxford University Press, Oxford, UK.

Hastings, G. 2012. Why corporate power is a public health priority. BMJ 345 , e5124.

Hopkins, R. 2009. The Transition Handbook. Finch Publishing, Sydney, NSW, Australia.

Korten, D.C. 1996. When Corporations Rule the World. Kumarian Press, BerrettKoehler Publishers, West Hartford, Connecticut, San Francisco, California, USA.

McMichael, A.J. 1993. Planetary Overload: Global Environmental Change and the Health of the Human Species. Cambridge University Press, Cambridge, UK.

McMichael, A.J. \& Butler, C.D. 2011. Promoting global population health while constraining the environmental footprint. Annual Review of Public Health 32, 179-97.

Marmot, M.G. \& Wilkinson, R.G. (eds) 2006. Social Determinants of Health. Oxford University Press, Oxford, UK. 
Meadows, D. 1999. Leverage Points. The Sustainability Institute, Hartland, Vermont, USA.

Nisbett, R.E. \& Wilson, T.D. 1977. Telling more than we can know: verbal reports on mental processes. Psychological Review 84, 231-59.

Ostrom, E. 2009. Beyond markets and states: polycentric governance of complex economic systems. The American Economic Review 100, 641-72.

Rockström, J., Steffen, W., Noone, K., Persson, Å., Chapin, F. III, Lambin, E., et al. 2009. Planetary boundaries:exploring the safe operating space for humanity. Ecology and Society 14, art 32 www.ecologyandsociety.org/vol14/ iss2/art32, accessed 16 February 2015.

Sachs, J.D. 2011. The Price of Civilization: Reawakening American Virtue and Prosperity. Random House Publishing Group, New York, USA (cited by Denniss and Richardson, 2013).

Ulrich, W. 2005. A Brief Introduction to Critical Systems Heuristics (CSH). ECOSENSUS project, Open University, Milton Keynes, UK. Available at: www.google.com.au/url? sa $=$ t\&rct $=\mathrm{j} \& \mathrm{q}=\&$ esrc $=$ s\&source $=$ web\&cd $=1 \&$ ved $=0 \mathrm{CC} 8 \mathrm{QFjAA} \&$ url $=\mathrm{http} \% 3 \mathrm{~A} \% 2 \mathrm{~F} \% 2 \mathrm{Fprojects} . \mathrm{kmi}$.open.ac.uk $\% 2$ Fecosen sus \%2Fpublications \%2Fulrich_csh_intro.pdf\&ei=nYVOU4-RNcWrkgXPso DQDA\&usg=AFQjCNEwcSksuF-MpexqngW1RbAFtfsVJA\&sig2=ZB0g2kj3 kjSyZcAV-xe4Ng\&bvm=bv.64764171,d.dGI, accessed 16 April 2014.

Wilkinson, R.G. \& Pickett, K. 2009. The Spirit Level: Why More Equal Societies Almost Always Do Better. Allen Lane, London, UK.

World Health Organization 1986. Ottawa Charter for Health Promotion. World Health Organization, Geneva, Switzerland. 
This text is taken from Health of People, Places And Planet:

Reflections based on Tony McMichael's four decades of contribution to epidemiological understanding, edited by Colin D. Butler, Jane Dixon and Anthony G. Capon, published 2015 by ANU Press, The Australian National University, Canberra, Australia. 